\title{
日本周辺の平均海面水位変動*
}

\author{
柳 哲雄・赤木竜也 ${ }^{\dagger}$
}

\section{Variation of the Mean Sea Level around Japan}

\author{
Tetsuo Yanagi and Tatsuya Akaki ${ }^{\ddagger}$
}

\begin{abstract}
Variation of the mean sea level around the Japanese Islands is investigated using yearly mean sea level data at 6 points from 1894 to 1990. Mean sea level has risen along the eastern coast of Japan 1-2 mm/year but it has fallen along the Japan Sea coast $0-1 \mathrm{~mm} /$ year. The prediction of the horizontal distributions of sea level for 2030 around Japan was found to rise on the basis of IPCC (Intergovernmental Panel of Climate Change ) and also this study.
\end{abstract}

\section{1.はじめに}

IPCC (Intergovernmental Panel of Climate Change) の第 1 作業部会 (気候変動の科学的評価)，のまとめによ ると, 人類による $\mathrm{CO}_{2}$ やメタンなど温室効果ガス排出の 対策を講じない場合, 地球の平均気温は 2025 年に $1{ }^{\circ} \mathrm{C}$, 2100 年に約 $3{ }^{\circ} \mathrm{C}$ 上昇する. そして，このような平均気温 上昇に伴う大陸上の水河の部分溶融や, 海水温上昇によ る海水の体積膨張により, 平均海面水位は 1985 年のレべ ルから 2030 年には $18 \mathrm{~cm}(8 \sim 29 \mathrm{~cm}), 2070$ 年には $44 \mathrm{~cm}$ $(21 \sim 71 \mathrm{~cm})$ 上昇すると予测されている (IPCC, 1990). 世界の平均海面水位は, 産業革命以降ここ100 年間に 約 $10 \mathrm{~cm} / 100$ 年=約 $1 \mathrm{~mm} /$ year の率で上昇している (Gornitz et al., 1982). この結果は観測期間 20 年以上で, 地 殼変動や地盤沈下の影響が少ないと考えられる世界中の 193 力所の検潮所のデータを地域毎に解析し, 世界 14 地 域の加重平均值を求め, さらに過去 6000 年の超長期地 殼変動を補正して得られたものである. また最近 50 年 間では約 $2 \mathrm{~mm} /$ year とその上昇率が大きくなっているこ

\footnotetext{
* 1993 年 3 月 24 日受領; 1993 年 9 月 20 日受理

$†$ 愛媛大学工学部士木海洋工学教室; 7790 松山市文京町 3

$\ddagger$ Department of Civil and Ocean Engineering, Ehime University; 3 Bunkyo, Matsuyama, 790 Japan
}

とも報告されている (Barnett, 1984).

海面水位は海底の観測基準面 (陸上のベンチマークに 対してその水深が決められている)に対する相対的な高 さとして観測されているので, 海水の体積増加のみなら ず，地盤の昇降によっても変動する. 実際過去において も, 世界で一様な平均海面水位変動が起こっているわけ ではなく, 北アメリカの東, 西海岸, ヨーロッパやアフリ カ沿岸などでは平均海面水位は上昇傾向にあるが, アジ アの東海岸, 中南米の西海岸, 南アメリカ西海岸では平均 海面水位はほとんど変化していないし, 北欧では大陸水 河の融解の後のリバウンドにより地盤が隆起して, 平均 海面水位は下降している (Gornitz et al. 1982, Barnett, 1984 ).

日本沿岸においてはここ100 年間平均海面水位はほと んど変化していない (岡田, 1988) と言われている. しか し, 1953〜1980 年の間の岡田 (1988) と同じ海面水位観 測データを用いて, Aubrey and Emery (1986) は Fig. 1 に示すように, 日本南岸では最大 $20 \mathrm{~mm} /$ year の割合で 平均海面水位が上昇 (地盤が沈降) しており, 日本海側で は最大 $4 \mathrm{~mm} /$ year の割合で平均海面水位が下降 (地盤が 上昇) していて，世界の平均海面水位変動率より 1 桁大 きい平均海面水位変動が起こっていると報告している. 


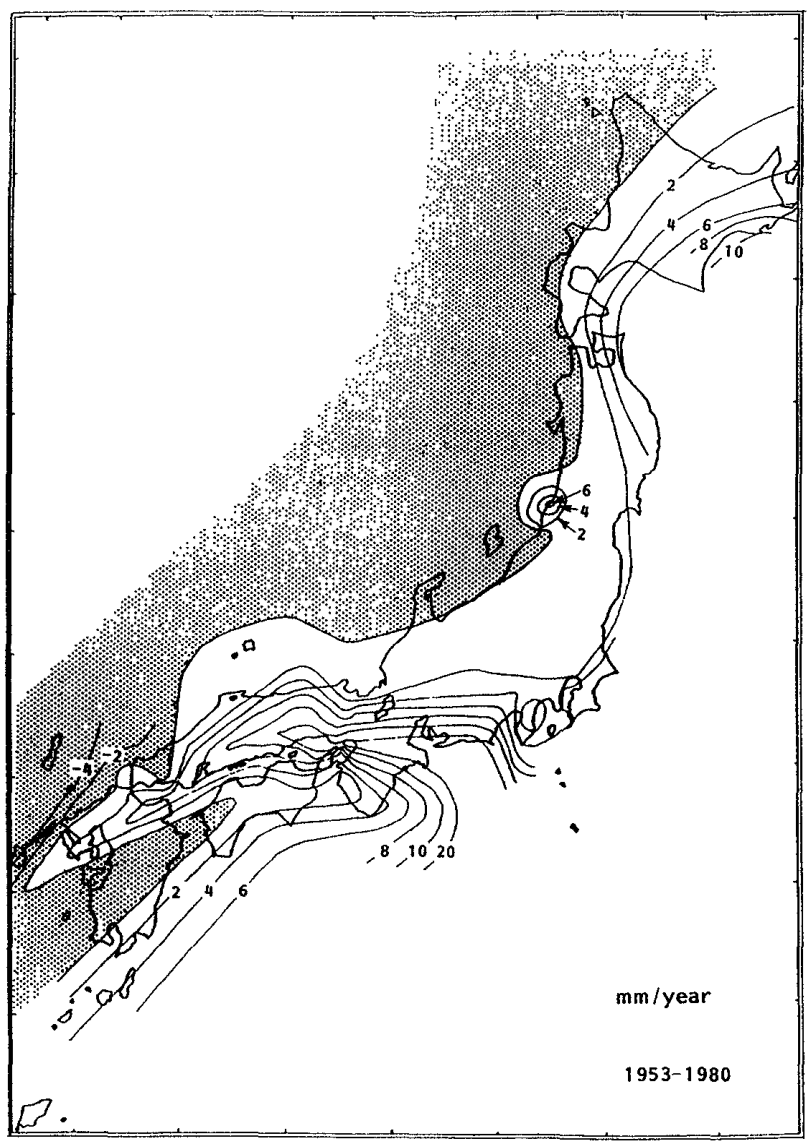

Fig. 1. Ratio of mean sea level variation (mm/year). The shadow area shows that where the mean sea level has sunk down (from Aubrey and Emery, 1986).

Fig. 1 は世界的によく引用されているが，このような平 均海面水位変動が実際に海水を原因として起こっている とは考えにくい，また, 村上・山田 (1992) は 1950〜1989 年の日本周㲽の 56 点の海面水位観測デ一タを解析して, 中部〜北日本で平均海面水位は $1.5 \sim 1.8 \mathrm{~mm} /$ year で上 昇しているが, 西日本では $1.0 \mathrm{~mm} /$ year で下降している と報告している。

以上述べたような海洋からの視点ばかりでなく, 古く から測地学者によって, 地盤の隆起・沈降を調べるため に, 日本周辺の平均海面水位変動は解析されてきている. たとえば, 加藤・津村 (1979) は 1951〜1978 年の日本全 国 100 力所の検潮所のデータを用いて, 三陸沿岸から北 海道東岸にかけて地盤は約 $10 \mathrm{~mm} /$ year で沈降し, 日本 海岸では約 $2 \mathrm{~mm} /$ year で地盤が隆起していると述べてい る. 壇原 (1977) も1950 1969 年の検潮記録を解析して ほぼ同様な結果を得ている。
これまで述べてきたように日本周汭の平均海面水位変 動に関する様々な既往の研究がある中で, IPCCによる 2030 年, あるいは 2070 年の世界の平均海面水位上昇予 測結果を日本周辺に適用しようとする場合, どの研究を 基礎において,どのような予測を行えばよいのかは明確 ではない.

そこで, 本稿では 1894〜1990 年 (約 100 年閒) の日本 周辺の潮位観測データをもとに, 日本周辺の平均海面水 位変動の実態を明らかにし，その結果とIPCC の予測結 果をもとにして, 2030 年の日本周辺の平均海面水位上昇 量の分布を定量的に予測をすることを試みる.

\section{2. 解析データ}

解析に用いた海面水位観測データは建設省国土地理院 海岸昇降検地センターによりまとめられた「日本列島沿 岸の年平均潮位とそのグラフ」(1991) から得たもので ある。

この冊子にまとめられている日本各地の 115 力所の $1894 \sim 1990$ 年の年平均海面水位の観測データをもとに して, 以後の解析を行った。

\section{3. 解析結果}

海面水位変動が海面気圧変動に対して一定の関係を有 していることはよく知られている，用いた海面水位観 測データは気圧補正が施されていないので，まず1894〜 1990 年の札幌, 東京, 福岡の気圧変動を調べてみた. その 結果を Fig. 2 に示す. 用いた生データは松山地方気象台 に保存されている気象庁年報より得た各点の年平均海面 補正気圧であるが, $1940 \sim 1950$ 年は気象庁年報が消失し ていたので, 線形補間を行ってある.この変動から最小二 乗法により求めた，この期間の海面補正気圧の線形トレン ドは札幌でー $0.0050 \mathrm{hPa} /$ year, 東京でー0.0056hPa/year, 福岡で+0.0017hPa/year であった. $+1 \mathrm{hPa}$ の海面気圧変 動に対して $-1 \mathrm{~cm}$ の海面水位変動が対応するので, 得ら れた平均海面気圧変動率より期待される平均海面水位变 動率は+0.056〜 -0.017mm/year である.この值は前述 した世界的な平均海面水位変動率である約 $1 \mathrm{~mm} /$ year の $6 \%$ に満たない. そこで, 以下の解析では日本周辺の平均 海面水位変動に及ぼす海面気圧変動の影響は一応無視し 


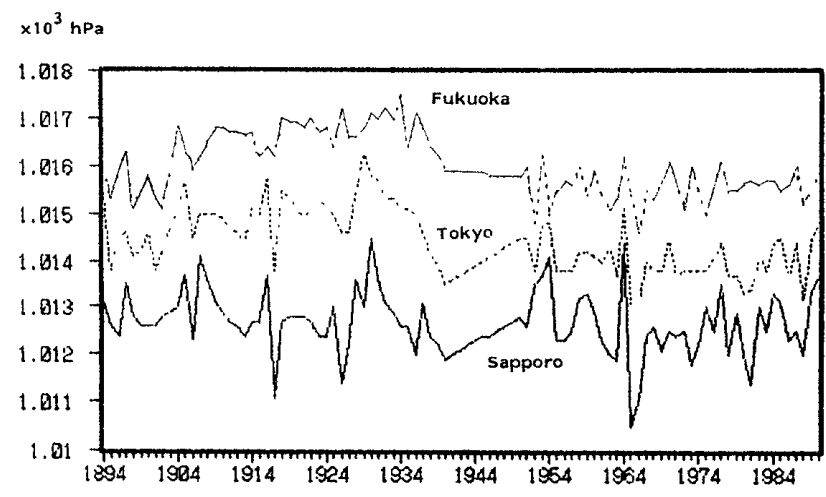

Fig. 2. Temporal variation in yearly-averaged sea level air pressure at Fukuoka, Tokyo and Sapporo from 1894 to 1990.

\section{て考えることにする．}

まずFig. 1 の検証を行ってみる.Fig. 1によれば，日本 周辺の平均海面水位変動率は最大 $20 \mathrm{~mm} /$ year に達して いる.この徝は世界の平均海面水位変動率より 1 桁大き く,このような平均海面水位変動が大陸水河の部分溶融 や海水の体積増加など, 海水そのものを原因として発生 している世界的な海面上昇と直接関連して発生している とは考えにくい.そこで, Fig. 1 で局所的に大きな平均 海面変動率を記録している鼠ケ関, 名古屋, 大阪, 神戸の 生データを調べてみた. 海岸昇降検知センター (1991)の グラフから選びだした生データの変動を Fig. 3 に示す. 図中白丸は 2 力月以内の欠測を含むデータから年間平均 海面水位を求めた年を表している. 鼠攵関の平均海面水 位が大きく変動した 1964 年は 6 月に M7.5の新潟地震 が発生した年にあたり，この年の約 $20 \mathrm{~cm}$ の平均海面水 位上舁の原因は海水そのものではなく, 鼠ケ関付近の地 盤の急激な沈降にあったと考えられる. また名古屋, 大 阪, 神戸の大きな平均海面水位変動は地下水の過剩な汲 み上げによる地盤沈下の影響が最も大きいことがすでに 明らかにされている(村上・山田，1992).

そこで,このような海水そのものに直接の原因がある とは考えにくい, 局所的に急激な平均海面水位変動を示 す観測点 23 点を除いた, 合計 30 点の同じ期間の記録を 解析して, 平均海面水位变動率を求めてみた. その結果 をFig. 4 に示す. 平均海面水位の上抙, 下降の全体の傾 向は, 伊豆半島と串本で平均海面水位が下降している以 外は, Fig. 1 とほぼ同様であるが, その変動率は+5.0〜 $-1.0 \mathrm{~mm} /$ year 程度で, 世界的な平均海面水位変動率と比
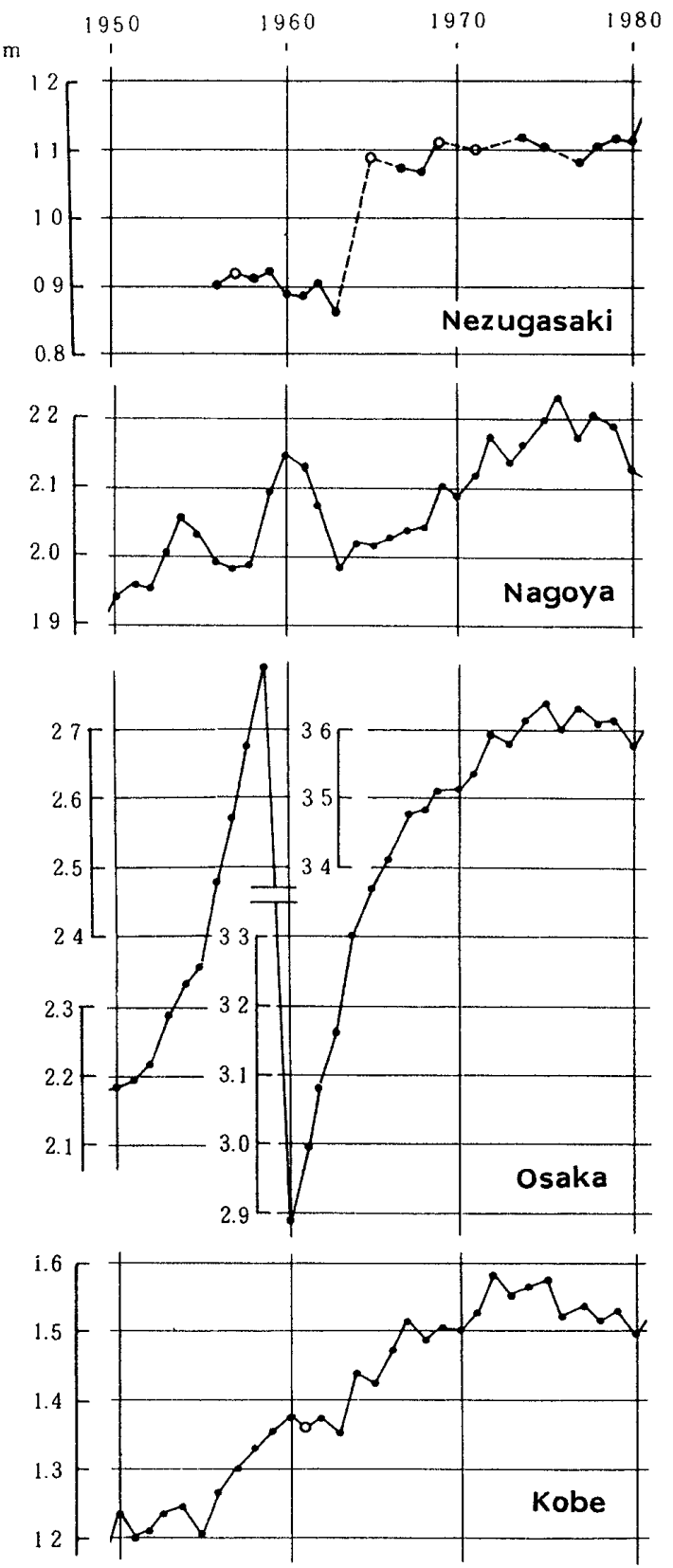

Fig. 3. Temporal variations in yearly-averaged mean sea level at Nezugasaki, Nagoya, Osaka and Kobe.

較して,ほぼ同程度の值となっている.したがって, 1953 〜1980 年の日本周辺の, 局地的な地盤変動を除いた, 平 均海面水位変動を表す図としては Fig. 1 ではなく, Fig. 4 を用いるべきであろう。

次に，より長期間の平均海面変動傾向を明らかにする ために, 1894〜1990 年の約 100 年間を通じて, ほぼ良好 な年平均海面水位データが得られている忍路, 輪島, 浜 


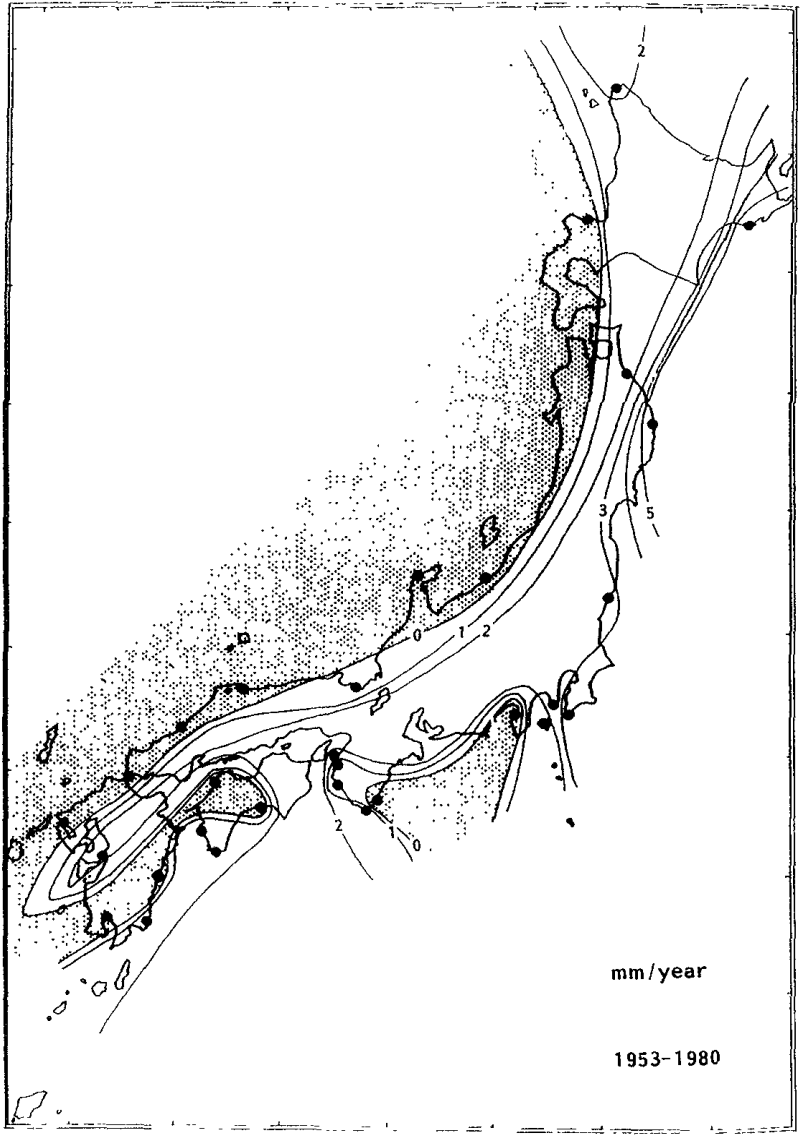

Fig. 4. Ratio of mean sea level variation (mm/year) from 1953 to 1980 . Black circles show the observation stations.

田 (外ノ浦), 細島, 串本, 鮎川の記録を解析して, 平均海 面水位変動率を求めた. Fig. 5 に示したこれらの観測点 の生データ (海岸昇降検知センター, 1991)の中の星印は, 験潮所の移設により記録が不連続となった年を示してい る. 鮎川の年平均海面水位が大きく下降している 1930 年代は, 1933 年に M8.3の三陸地震が発生し, 津波によ る死者が 3008 人を数えるといら事件が起こっている。し たがって, 鮎川の 1930 年代の大きな平均海面水位変動は この三陸地震に関連したものと考えられる.ただ1900〜 1920 年代の平均海面水位 (約 $1.6 \mathrm{~m}$ ) と, 験潮所を移設し た後の 1940 年代後半の平均海面水位 (約 $1.5 \mathrm{~m}$ ) はほぼ 一致させて女るので, 100 年間全体の平均海面水位変動 率を求める場合に，この記録を用いることに問題はない と考えられる.最小二乗法により各点の約 100 年間の線 形トレンドを求めた結果を Fig. 6 に示す. 三陸・東海道 沿岸で平均海面水位は 1.0 2.0 mm/year で上昇, 日本海 北部沿岸と九州東部海岸で $0 \sim 0.5 \mathrm{~mm} /$ year で下降して
いる.

さらに, Fig. 5 において 6 点のデータがそろって得られ ている 1906〜1984 年の観測データを用いて行った EOF 解析の結果を Fig. 7 に示す. 第 1 モードは全体の変動 の $63.1 \%$ を説明するが, 鮎川と他の点の位相は逆になっ ていて,その時間変動は Fig. 5 に示した鮎川の平均海面 水位変動とほぼ同様になっている.すなわち, 1930 年代 後半に大きな変動を示し, 1950 年以降上昇傾向が顕著に なっている.また第 2 モードは全点で同位相の変動傾向 を示し, その時間変動には数年〜十数年周期の短周期変 動が顕著に現れている。

\section{4. 考察}

平均海面水位を変化させる原因としては 1) 地殼の上 昇・沈降, 2) 海水の水温変化による海水の体積変化, 3) 水河の溶融による海水の体積变化, 4) 海洋そのものの体 積変化, 5) 風系や海流の変動などが考えられる.

このうち4)に関しては,プレートの運動に関連した海 洋そのものの体積变化を定量的に見積もることは現在の 所不可能なので, 今の所評価出来ない，5）の効果は主に 周期数年〜十数年といった短期的な平均海面水位変動に 寄与していて, 今回求めた約 100 年間の平均海面水位変 動に直接寄与しているとは考えられない. Fig. 7 に示し た第 2 モードの短周期の時間変動が 5) の影響を表して いるのかもしれない。

Gornitz et al. (1982) は過去 100 年間の世界の平均海 面水位変動率 $1 \mathrm{~mm} /$ year のちち, その半分は2) で, 残り の半分は 3) で説明可能であると述心゙ている.ただ2)に 関しては, 日本周辺の暖水塊や泠水塊の配置の変化で局 所的な海面水位変動を起こす可能性がある. 友定 (1991) は日本近海の 1963 1985 年の $0,50,100,200 \mathrm{~m}$ 層の水 温観測結果を整理して, 最小二乗法により 23 年間の水温 変動傾向を見積もった. $100 \mathrm{~m}$ 層の結果は Fig. 8 に示す ようであって(他の層もほぼ同様な結果となっている), 東海道沖の䄪 $0.01{ }^{\circ} \mathrm{C} /$ year の水温上昇を除けば, 日本近 海では平均水温は $0.01^{\circ} \mathrm{C} /$ year で下降している.このこ とは水温だけの影響を考えた場合には東海道沖でのみ平 均海面水位は上昇し, 他の地点では平均海面水位は下降 することになる.しかし, Figs. 4, 6 にはそのような傾向 は伺えない. したがって, 日本周辺の平均水温変動が日 

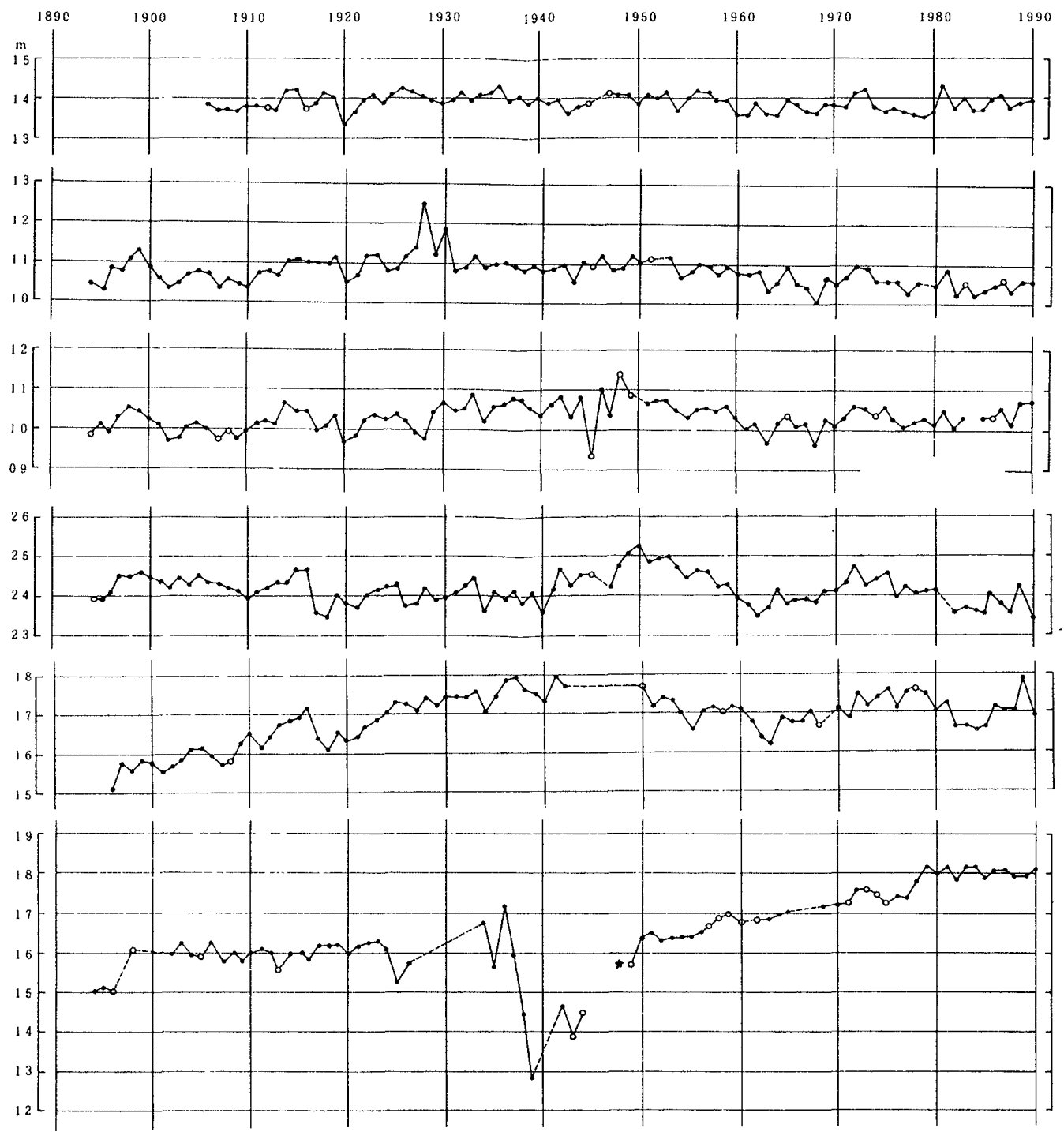

Fig. 5. Temporal variations in yearly-averaged mean sea level at Oshoro, Wajima, Hamada, Hosojima, Kushimoto and Ayukawa.

本周辺の平均海面水位変動に直接影響を与えているとは 考えにくい，定量的には平均水温 $10^{\circ} \mathrm{C}$, 平均塩分 $34 \mathrm{psu}$ の $200 \mathrm{~m}$ の水柱の水温が $1{ }^{\circ} \mathrm{C}$ 上昇すると, 体積膨張によ り, 海面水位は約 $3 \mathrm{~cm}$ 上昇する (岡田, 1988). したがっ て $0.01{ }^{\circ} \mathrm{C} /$ year $\sigma$ 平均水温変動は約 $0.3 \mathrm{~mm} /$ year $の$ 平均 海面水位変動しか生じない.

いずれにしても, Gornitz et al. ( 1982 ) や Barnett ( 1984 ) が示したような2)や3)による平均海面水位上昇 は世界全域で同様に生じているはずであり，Fig. 6 に示 したように, 日本周辺において平均海面水位が上昇, 下降 のパターンを示すことは2)や3)による約 1～2mm/year の世界全体の平均海面水位上昇に加えて, 日本周辺の平
均海面水位を変動させる別の原因があることを示唆して いる.

平均海面水位を変動させる 1)～5) の原因に対する消去 法から考えれば, Fig. 7 に示したEOF の第 1 モードは1) の日本周辺の地殼変動による平均海面水位変動を表して いると考えられる。すなわち,フィリピン海プレートと 太平洋プレートがユーラシアプレートと北米プレートの 下部にそれぞれ潜り込んでいる日本南岸と日本東岸では 地款が沈降して平均海面水位は上昇し, 反対に日本海岸 ではその反動として地殼は上昇し, 平均海面水位は下降 しているのだろう。第 1 モードの時采列によれば,この ような变動は 1950 年以降大きくなっている. 実際, 1953 


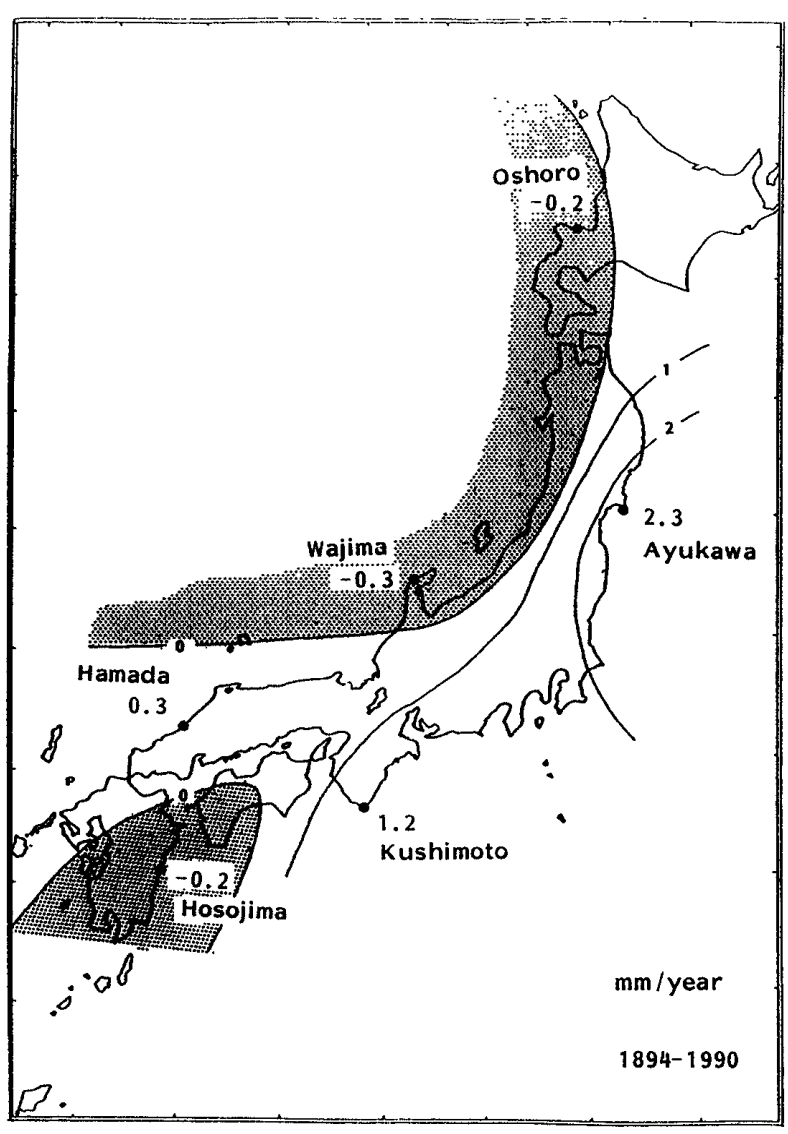

Fig. 6. Ratio of maen sea level variation (mm/year) from 1894 to 1990 . Black circles show the observation stations.

〜1980 年の観測データを用いた解析結果を示す Fig. 4 では三陸沿岸の平均海面水位変動率は約 $+5 \mathrm{~mm} /$ year と なっていて, 100 年間の観測データを用いた Fig. 6 の約 2 倍となっている.

Gornitz et al. ( 1982 ) による 1mm/year の世界全 域の平均海面水位上舁が日本周辺でも最近 100 年間起 こっていたとすれば, Fig. 6 の結果から全域で $1 \mathrm{~mm} /$ year を差し引いたものが，日本周辺の地殼変動率を表してい ることになる.すなわち, 日本東岸や南岸の地盤は 0 ～ $1.0 \mathrm{~mm} /$ year で沈降し, 日本海岸の地盤は $1.0 \mathrm{~mm} /$ year で 隆起していることになる.また Barnett（1984）による $2 \mathrm{~mm} /$ year の世界全域の平均海面水位上昇が日本周辺で も最近 50 年間起こっていたとすれば, Fig. 4 の結果から， 日本東岸や南岸の地盤は $1.0 \sim 4.0 \mathrm{~mm} /$ year で沈降し, 日 本海岸の地盤は $1.0 \mathrm{~mm} /$ year で隆起していることになる.
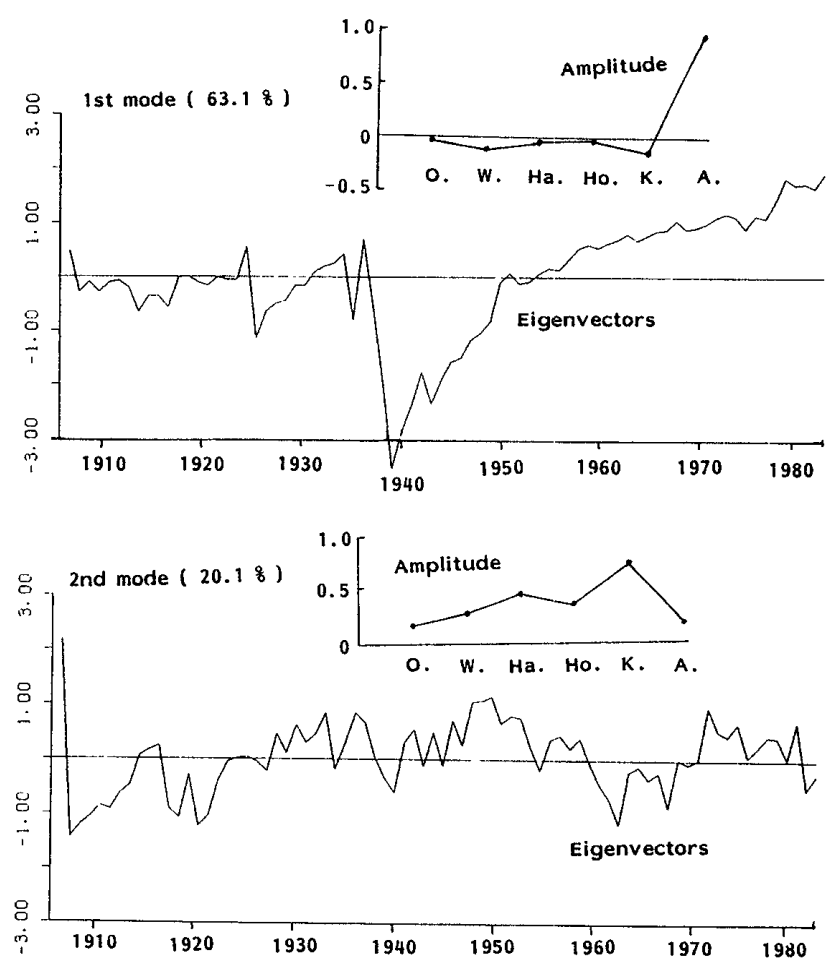

Fig. 7. Results of EOF analysis on the data of mean sea level around the Japanese Islands from 1906 to 1984 .

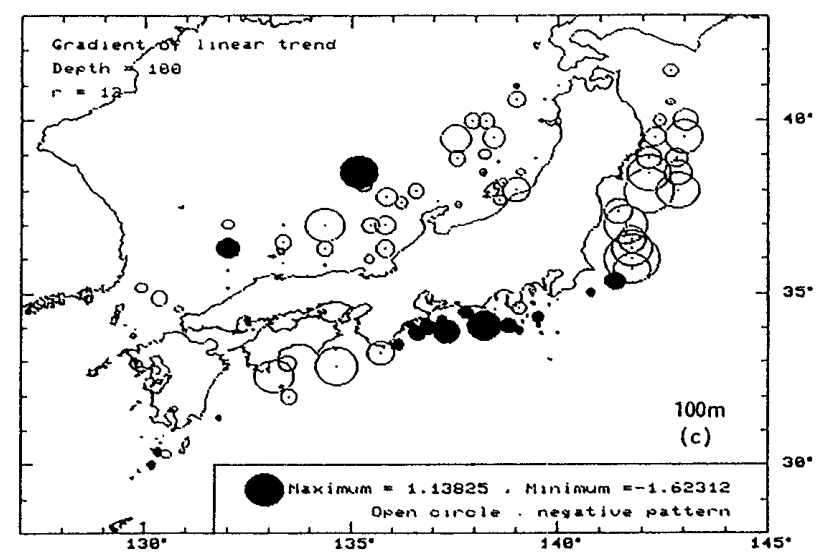

Fig. 8. Ratio of mean water temperature at 100 $\mathrm{m}$ depth around Japan. Black circles show the stations where mean water temperature has risen and open circles mean water temperature has fallen (Tomosada, 1991).

\section{5. おわりに}

平均海面水位が上昇すれば，主に沿岸地域に集中して いる人類の生命や財産を保護するために, 海岸堤防を高 

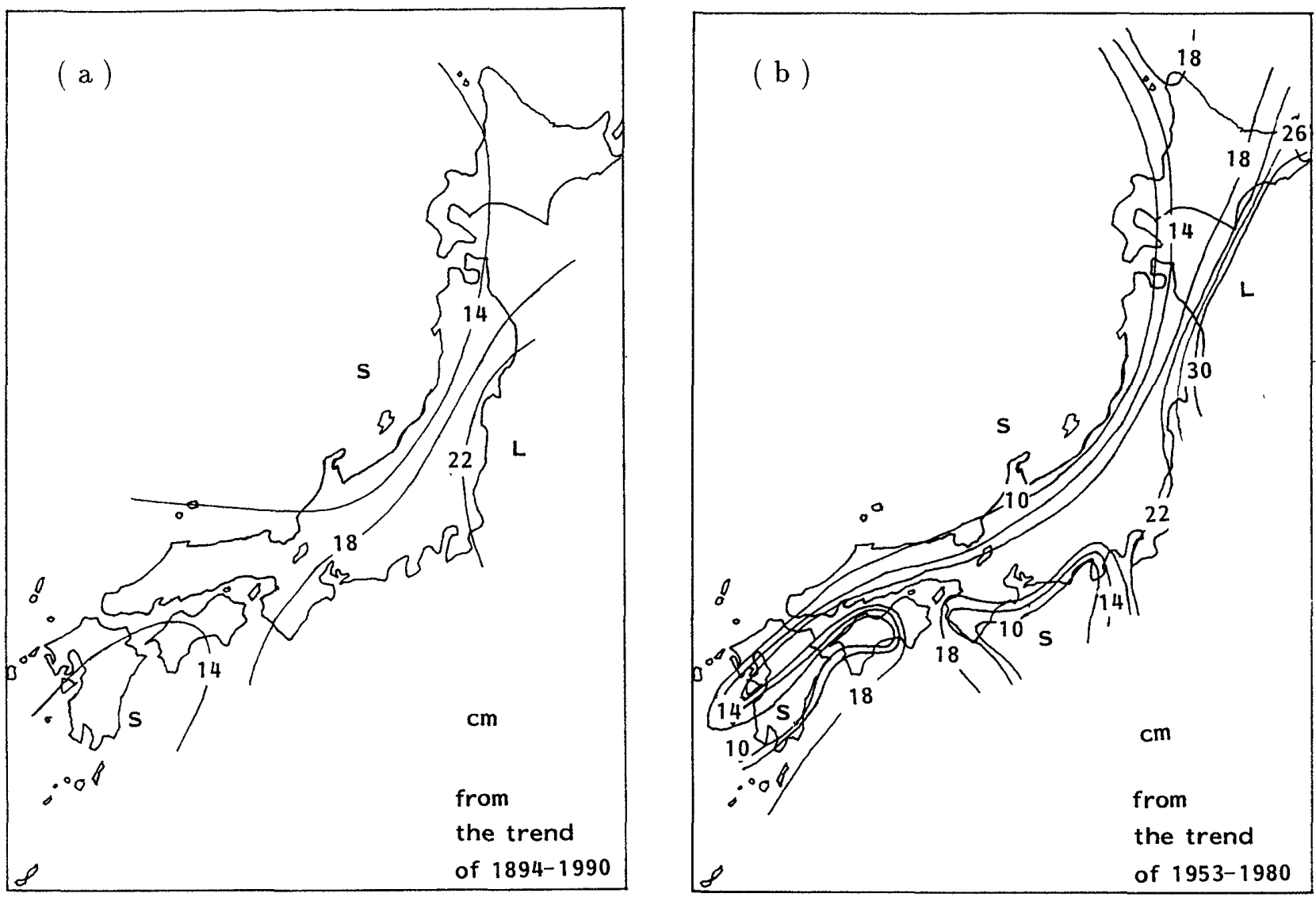

Fig. 9. Predicted distribution of mean sea level rise for 2030 refered to that of 1985 on the basis of the trend of 1894-1990 ( a ) and that on the trend of 1953-1980 ( b ).

くしたり，内水排除機能を強化したり，地下水の塩水化 を防止したり,など様々な海面上昇対応策を講じる必要 が生じてくる．このような多額の費用を必要とする社会 的な諸対策を講じようとすれば, 対策工事の優先順位を 決定するために, 各地で精度の良い海面上昇予測が必要 とされることは言うまでもない.すなわち諸々の対策工 事は平均海面水位上昇率の大きい所から行われるべきで ある。

IPCC の予測結果である, 1985 年に対する 2030 年の 平均海面水位上昇量 $18 \mathrm{~cm}$ は, 主に海水の膨張と大陸水 河の融解に伴うもので, 世界で一様に起こると考えられ る.これに対して日本周辺では Fig. 6 や Fig. 4 に示す ように日本南岸や日本東岸の地盤は $0 \sim 4.0 \mathrm{~mm} /$ year で 沈降し, 日本海岸の地盤は約 $1.0 \mathrm{~mm} /$ year で隆起してい るので, 実際の日本周辺の平均海面水位上舁は世界全体 の平均海面水位上昇にこのような地盤の沈降・隆起の影 響を加えた形で現れることになる．したがって Fig. 6， Fig. 4 と IPCC の予測結果をもとにした, 1985 年の平均
海面水位に対する 2030 年の平均海面水位の上昇予測分 布は, Fig. 9 のよになるだろう.

今後さらに研究を進めて, 日本近海の地殻と平均海面 水位のより正確な変動傾向を定量的に明らかにして, 平 均海面水位変動の精度の良い将来予測を行えるようにし ていきたいと考えている.

本研究を進めるにあたり, 貴重な議論をして頂いた愛 媛大学工学部武岡英隆助教授, データ整理に協力して頂 いた同, 磯田 豊助手, 貴重なコメントを頂いた査読者の 方に感謝の意を表する. なお, 本研究は文部省科学研究 費による総合研究 A「東アジア沿岸域における地球温暖 化の実態・影響・対応策に関する総合的研究」(04302042, 研究代表者, 渡邊 晃東京大学工学部教授) の一部であ ることを付記する。

\section{References}

Aubrey, D. G. and K. O. Emery (1986): Relative sea levels of Japan from tide-gauge records, Geol. Soc. Am. Bull., 
97, 194-205.

Barnett, T. P. (1984): The estimation of global sea level change: a problem of uniqueness. J. Geophys. Res., 89(C5), 7980-7988.

壇原 毅 (1977): 大地を測る. 出光科学叢書 11, 出光書店, 東 京, 241p.

Gornitz, V., L. Lebedeff and J. Hansen (1982): Global sea level trend in the past century. Science, 215, 1611-1614.

IPCC (1990): Climate Change. Cambridge University Press, Cambridge, 365p.

海岸昇降検知センター (1991): 日本列島沿岸の年平均潮位と そのグラフ. $83 \mathrm{p}$.

加藤照之・津村建四郎 (1979): 潮位記録から推定される日本の 垂直地款変動 $(1951 １ 978)$. 地震研究所彙報, 54, 559-628.

岡田正実 (1988): 平均潮位の長期変動. 気象問題懇锬会レポー 卜, 気象庁, $72 \mathrm{p}$.

友定 彰 (1991): 海洋環境の変動. 木村記念会誌「潮」，第 3 号, 7-21.

村上和男 ・山田邦明 (1992): 我国沿岸の海面水位の長期変動 の特性とその要因. 海岸工学講演会論文集, 39, 1026-1030. 